\title{
Viruses and Autoimmunity: A Review on the Potential Interaction and Molecular Mechanisms
}

\author{
Maria K. Smatti ${ }^{1}$ (D) Farhan S. Cyprian ${ }^{2}$, Gheyath K. Nasrallah 1,3 ${ }^{(D)}$, Asmaa A. Al Thani 1,3, \\ Ruba O. Almishal ${ }^{2}$ and Hadi M. Yassine 1,3,*(D) \\ 1 Biomedical Research Center, Qatar University, Doha 2713, Qatar \\ 2 Basic Medical Science Department, College of Medicine-QU Health, Qatar University, Doha 2713, Qatar \\ 3 Department of Biomedical Sciences, College of Health Science-QU Health, Qatar University, \\ Doha 2713, Qatar \\ * Correspondence: Hyassine@qu.edu.qa; Tel.: +974-4403-6819
}

Received: 7 July 2019; Accepted: 31 July 2019; Published: 19 August 2019

\begin{abstract}
For a long time, viruses have been shown to modify the clinical picture of several autoimmune diseases, including type 1 diabetes (T1D), systemic lupus erythematosus (SLE), rheumatoid arthritis (RA), Sjögren's syndrome (SS), herpetic stromal keratitis (HSK), celiac disease (CD), and multiple sclerosis (MS). Best examples of viral infections that have been proposed to modulate the induction and development of autoimmune diseases are the infections with enteric viruses such as Coxsackie B virus (CVB) and rotavirus, as well as influenza A viruses (IAV), and herpesviruses. Other viruses that have been studied in this context include, measles, mumps, and rubella. Epidemiological studies in humans and experimental studies in animal have shown that viral infections can induce or protect from autoimmunopathologies depending on several factors including genetic background, host-elicited immune responses, type of virus strain, viral load, and the onset time of infection. Still, data delineating the clear mechanistic interaction between the virus and the immune system to induce autoreactivity are scarce. Available data indicate that viral-induced autoimmunity can be activated through multiple mechanisms including molecular mimicry, epitope spreading, bystander activation, and immortalization of infected B cells. Contrarily, the protective effects can be achieved via regulatory immune responses which lead to the suppression of autoimmune phenomena. Therefore, a better understanding of the immune-related molecular processes in virus-induced autoimmunity is warranted. Here we provide an overview of the current understanding of viral-induced autoimmunity and the mechanisms that are associated with this phenomenon.
\end{abstract}

Keywords: autoimmunity; viral infections; molecular mechanisms; molecular mimicry

\section{Introduction}

Autoimmune diseases (AID) develop as a result of an aberrant immune response in recognizing self and non-self-antigens. Currently, there are more than 80 identified types of autoimmune disorders [1]. Although the etiologies of several autoimmune disorders remain completely understood, multiple factors have been linked to autoimmune responses, including genetics, age, environment, as well as viral infections. Viruses have been considered as major environmental factors that trigger the autoimmune phenomena in genetically susceptible individuals [2,3]. Multiple mechanisms have been proposed to explain the breakdown of self-tolerance by viral infections (Figure 1). Traditionally, it was believed that viruses carry structurally similar antigens to self-antigens, which activate B and $\mathrm{T}$ cells and lead to a cross-reactive response against both self- and non-self-antigens, a mechanism known as "molecular mimicry" [4]. Molecular mimicry has been described for herpes simplex 
virus (HSV)-induced stromal keratitis [5], virus-induced diabetes [6], autoimmune myocarditis that is mediated by Coxsackie virus infection [7], Theiler's murine encephalomyelitis virus-induced demyelinating disease (TMEV-IDD) [8], and several others [9]. Another hypothesized mechanism is the "bystander activation", whereby a non-specific and an over-reactive antiviral immune response creates a localized pro-inflammatory environment along with the release of self-antigens from the damaged tissue. These self-antigens are subsequently taken up and presented by antigen presenting cells (APC) to stimulate the previously non-responsive, yet autoreactive $\mathrm{T}$ cells in the vicinity triggering autoimmunity [10]. A related mechanism is called "epitope spreading", in which a viral infection triggers the release of more self-antigens and the de novo activation of autoreactive cells, which consequently spread to target additional self-epitopes [9]. Both molecular mimicry and bystander activation have been observed in the experimental autoimmune encephalomyelitis (EAE) model of multiple sclerosis (MS) [11], West Nile virus (WNV)-mediated myasthenia gravis (MG) [12], TMEV-IDD [13], and other disorders [9]. Moreover, viruses may immortalize autoreactive effector cells as observed in Epstein-Barr virus (EBV)-infected B cells [14]. While several hypotheses have been proposed to understand the mechanisms underlying virus-induced autoimmunity, the precise contribution of these mechanisms are not yet fully understood. This review summarizes the recent findings on virally induced autoimmunity and the potential underlying mechanisms triggering the development of this disorder.

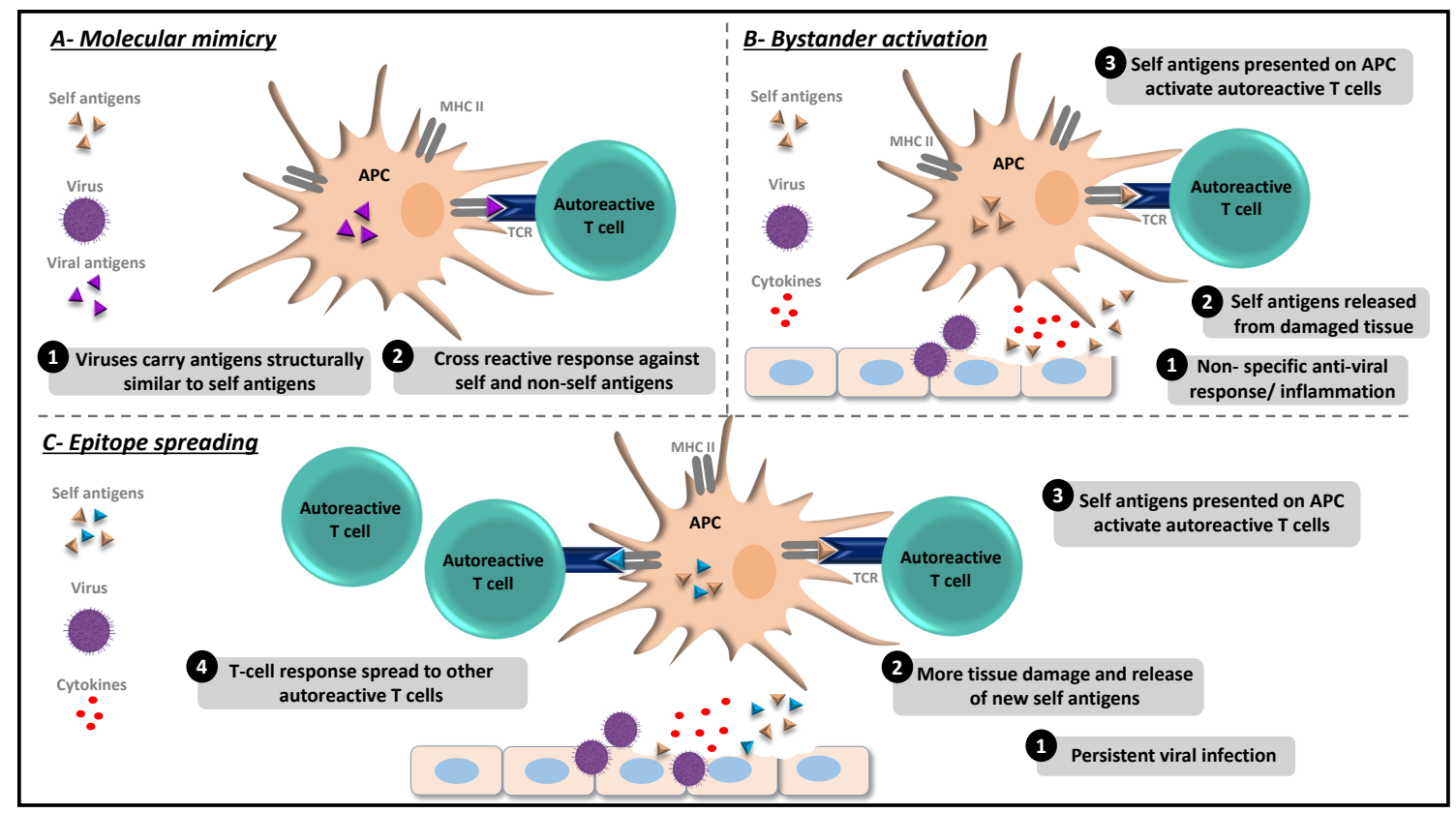

Figure 1. Mechanisms of virus-induced autoimmunity. (A) Molecular mimicry model: (1) Viruses carry epitopes structurally similar to self-epitopes. (2) Presentation of viral epitopes by antigen presenting cells (APCs) activate autoreactive T cells that bind to both, self and non-self-antigens, and induce tissue damage. (B) Bystander activation model: (1) Non-specific and over reactive antiviral immune responses lead to the liberation of self-antigens and release of inflammatory cytokines from the damaged tissue. (2) Self-antigen is taken up and presented by APCs. (3) Autoreactive T cells activated by APCs, leading to tissue destruction. (C) Epitope spreading model: (1) Persistent viral infection. (2) Continued tissue damage and release of new self-antigens. (3) Self-antigens are taken up and presented by APCs. (4) Nonspecific activation of more autoreactive T cells leading to autoimmunity.

\section{Viral Infections and Induction of Autoimmunity}

\subsection{Enteric Infections}

Enteroviruses are considered the main viral candidates for causing type 1 diabetes in humans [15]. Seasonal incidence of type 1 diabetes has been reported subsequent to enterovirus infections since 
$1969[16,17]$. Although the role of enteroviruses in type 1 diabetes has been investigated for more than 40 years, the etiological link is still enigmatic [18]. A higher frequency of enterovirus infections has been reported among siblings who develop type 1 diabetes as compared to nondiabetic controls [19]. Additionally, higher titers of enterovirus antibodies were found in pregnant mothers whose children later developed type 1 diabetes [19]. Furthermore, association between enteroviral infections and beta cell autoimmunity has been reported on several occasions. For example, in type 1 diabetes-genetically susceptible children, a seasonal detection of autoantibodies matched the seasonal occurrence of enteroviruses infections, suggesting the contribution of enteroviruses to autoimmune diabetes [20]. In another study, signs of enterovirus infections were detected in parallel with the first appearance of diabetes-associated autoantibodies [21]. Correspondingly, Elshebani et al. found that certain enterovirus strains that are isolated from type 1 diabetes patients affected the function of beta cells, and induced cell destruction in vitro [22]. Similarly, enteroviruses have been found in intestinal biopsies from diabetic patients, suggesting the possibility of an ongoing persistent enterovirus infection in the gut mucosa of type 1 diabetes patients [23]. Furthermore, a recent systematic review that analyzed 24 published papers documented a significant association between enteroviruses and autoimmunity/type 1 diabetes [24].

\subsubsection{Coxsackie B Viruses}

Coxsackie $B$ virus (CVB) is the most prevalent enterovirus in pre-diabetic and diabetic patients [15]. Several studies have reported the presence of CVB RNA in the blood of type 1 diabetes patients [25-28]. Juhela et al. found that T cell response to CVB4 (serotypes 4 in Coxsackievirus group B) is enhanced in children with type 1 diabetes, and this might be as a result of enterovirus-specific $\mathrm{T}$ cell being trapped in the pancreas [29]. In addition, a post-mortem examination of a deceased diabetic child revealed the death of beta cells and the presence of a lymphocytic infiltrate in the islets of Langerhans [30]. In further support of this finding, CVB4 was propagated in mouse pancreatic cells, and when those cells were inoculated into susceptible mice, they developed autoimmune diabetes [30]. Dotta et al. detected CVB4 in pancreatic tissue from three out of six patients with type 1 diabetes. In fact, the virus was able to infect beta cells originating from non-diabetic donors, leading to beta cell functional impairment and strong Natural Killer (NK) cells-mediated inflammation [31]. This observation could be attributed to the high expression of type-I interferon (IFN-1) in beta cells following CVB infection, which leads to rapid beta cell death [32]. Evidence of inflammation and direct cytolysis of beta cells has been shown to produce autoantigens that initiate autoimmunity in turn [15]. Importantly, age seems to play a significant role in the development of virus-induced diabetes. In this regard, infection with CVB4 has been shown to enhance type 1 diabetes in eight-week-old NOD mice but not in a younger age group, suggesting that CVB4 infection can contribute to diabetes progression, only if a threshold level of pre-existing autoreactive $\mathrm{T}$ cells were accumulated in the pancreatic islets [33]. Virus-induced inflammatory cytokines are also thought to play an important role in the induction of autoimmunity in a time-dependent manner. For example, expression of Tumor necrosis factor alpha (TNF- $\alpha$ ) in the pancreatic islets has been shown to enhance or abrogate autoimmune diabetes depending on the time of expression [34].

The molecular basis of autoimmunity in CVB4 infection is proposed to be a molecular mimicry [35], where the $2 \mathrm{C}$ non-structural $\mathrm{CVB}$ protein has a shared sequence with the glutamic acid decarboxylase 65 enzyme (GAD65), which is predominantly expressed in pancreatic beta cells [36]. This result aligns with previous studies that have investigated the immunological cross-reactivity caused by sequence similarity between self- and non-self-antigens. Particularly GAD65 was found to play an important role in the pathogenesis of type I diabetes as a target autoantigen [37], where the ensuing immune response to GAD65 has been detected before the onset of clinical diabetes [35]. In this regard, it is of note that T cells isolated from type 1 diabetes patients were shown to react with both GAD65 and 2C protein, however, other studies have demonstrated that healthy control groups can also have reactive 
T cells to GAD65 [38]. This immunological cross-reactivity may not provide the initiative event for triggering diabetes, but can act as an enhancer for disease development [15].

Bystander activation was also a suggested mechanism by which CVB4 induce or accelerate diabetes. Mouse studies have indicated that by evoking beta cells damage, CVB4 infection promotes the release of self-antigens, which are then presented by macrophages to autoreactive T cells [32].

On the contrary, some studies have not found convincing evidence supporting the CVB-induced diabetes hypothesis [39]. Notably, Sarmineto et al. showed that although an enterovirus epidemic occurred in Cuban population between 2000 and 2001, diabetes rate in the population was not affected [18]. On the other hand, other studies have demonstrated that infection with CVB during the first year of life can have a protective effect against type 1 diabetes [29]. This protection was attributed to the developmental stage of the adaptive immune system where viral infections trigger specific immune responses, including activation of T regulatory (Treg) cells and induction of suppressors which collectively hinder autoimmunity [15]. Furthermore, CVB infection was found to be protective through enhancing Treg cells in individuals who are genetically susceptible to type 1 diabetes but not insulitis, therefore inhibiting islet-specific $T$ cell autoimmunity [17]. However, it is yet to be determined how often CVB can induce autoimmunity, and what are the factors that contribute to beta cells destruction and diabetes development or protection [15].

Taken together, molecular mimics of islet autoantigens have been strongly suggested as a factor for CVB-induced autoimmunity. However, bystander activation of autoreactive $\mathrm{T}$ cells and rapid death of CVB-infected beta cells are also potential mechanisms that could contribute to diabetes.

\subsubsection{Rotavirus}

Several studies investigated the role of rotavirus in the induction of autoimmunity in human and animal models, suggesting bystander induction of autoimmunity. Based on serological analysis of rotavirus antibodies and islets autoantibodies, Honeyman et al. suggested that rotavirus infection might trigger autoimmunity to pancreatic islets in high-risk children [40]. In contrast, a larger study cohort showed that rotavirus infections are unlikely to trigger beta cell autoimmunity in genetically susceptible children [41]. Studies of rhesus monkey rotavirus (RRV) infection in NOD mice indicated that RRV can induce diabetes without pancreatic infection, but it depends on the presence of insulitis with involvement of Th1 activation and proinflammatory cytokines release [42,43]. Interleukin 1 and 6, the candidate proinflammatory cytokines, are known to suppress Treg functionality allowing unchecked adaptive autoimmune response. The time of infection, age, and insulitis status seems to affect the outcomes of infection in terms of delaying, accelerating, or not affecting the onset of diabetes [43]. Moreover, rotavirus acceleration of diabetes is strain-specific, as infection of mice with RRV but not the CRW-8, which is an Australian porcine rotavirus serotype that cross react with human rotavirus serotype 3, has enhanced disease development [44]. Pane et al. proposed that diabetes acceleration by rotavirus in NOD mice occur via bystander activation: Rotavirus degraded dsRNA induce Toll-like receptor 7 (TLR7) signaling, leading to release of type-I interferon and lymphocyte activation, including autoreactive T cells, which in turn exacerbate diabetes-related autoimmunity [42]. Although TLR7 has been implicated in the bystander activation, the melanoma differentiation-associated protein 5 (MDA5), might also have a role in rotavirus-induced type-I IFN expression, and thus diabetes progression [32]. If viral-induced diabetes can occur through nonspecific mechanisms without pancreatic viral infection, e.g., proinflammatory cytokine response and lymphocyte activation, this suggests that multiple other viruses can produce similar effect [32], and hence, further studies in the field are necessary.

\subsection{Respiratory Infections: Influenza A Virus (IAV) as an Example}

Influenza viruses primarily replicate in the respiratory tract; however, viral replication in pancreatic islets and other internal organs has also been reported and linked to bystander activation of the immune system. In 1990, Roman et al. reported that influenza virus induced insulitis and diabetes in transgenic mice expressing hemagglutinin in the pancreatic beta cells [45]. Moreover, multiple studies and case 
reports in the last ten years have demonstrated the possible association between influenza virus infection and diabetes development. Using both, avian strains (H7N1 and H7N3) and human strain (H1N1), Capua et al. reported that influenza viruses are able to grow in human pancreatic cell lines in vitro, whereas they lead to tissue damage and diabetes in turkeys [46].

Influenza viruses can reach the pancreas through viremia $[47,48]$ and replicate in pancreatic cells from both, exocrine and endocrine origins [46]. The virus can also find its way to the pancreas through reflux from the gut to the pancreatic duct, where it finds a tolerant environment containing appropriate cell receptors and susceptible cells. Primarily, human pancreatic cells express both alpha-2,3 and alpha-2,6 sialic acid receptors, which theoretically allow both human and avian influenza strains to replicate [46].

Clinically, the onset of diabetes and other pancreatic diseases have been linked to influenza infections. In a case report from China in 2012, diabetic ketoacidosis was documented in a young woman after H1N1 infection [49]. In another case, a patient converted from type 2 to type 1 diabetes after influenza A virus infection during H1N1 pandemic in 2009 in Japan. This patient had a human leukocyte antigen (HLA) pattern associated with type 2 diabetes, and developed deterioration of glycemic control after the infection [50]. These cases have shed light not only on the role of viral infections, but also on the susceptibility of these patients in development of diabetes. In a study investigating type 1 diabetes onset in children hospitalized with 2009 pandemic influenza A (H1N1) virus, it was found that three children $(7 \%)$ had ketoacidosis as an indication of type 1 diabetes, suggesting that H1N1 virus can be involved in disease development [51]. In addition, a recent study with a large cohort found that young children presented with respiratory infections such as influenza like illness, had increased risk of developing pancreatic islet autoimmunity [52].

Several studies have linked upper respiratory infections to transient increase in type-I IFN expression preceding autoimmunity/diabetes development [53]. Similarly, it was found that influenza virus stimulated IFN- $\alpha$ production from plasmacytoid dendritic cells (pDC), which is associated with Th1-mediated autoimmunity type 1 diabetes development [54]. Further, IAV infection induced significantly higher pDC-dependent IFN- $\alpha$ expression in PBMCs obtained from diabetic patients compared to those from healthy controls [54]. This increase in IFN- $\alpha$ expression was associated with increased numbers of $\mathrm{pDCs}$, which in turn could contribute to the bystander activation of autoreactive $\mathrm{T}$ cells. More recently, it was reported that a highly functional CD8+ $\mathrm{T}$ cell response is elicited by alternative reading frame (ARF) epitopes encoded by NS1 mRNA of IAV, which might have important implications on IAV-induced autoimmunity [55].

Although studies have linked IAVs to diabetes, their exact role in disease prognosis and pathogenies is yet to be explored. Viral replication is thought to cause cell damage and cytokines production, similar to conditions linked to diabetes prognosis. More specifically, in situ hybridization experiments of pancreatic tissue after infection with influenza virus have indicated that viral nucleoprotein was detected in beta cells, with reduction in the number of cells staining for insulin [46]. This clearly suggests the potential effect of influenza replication on beta cells damage and insulin levels, leading to diabetes.

In the last decade, a number of studies had associated influenza infection or vaccination to type 1 narcolepsy (T1N), a chronic sleep disorder associated with autoimmune destruction of hypocretin (HCRT) neurons in the hypothalamus. This disorder is linked to the HLA-DQB1*0602/DQA1*01:02 haplotype, T cell receptors (TCR) and other immune loci, suggesting the involvement of autoimmune response in the disease pathophysiology [56,57]. However, the associated autoantigens are still not identified. Observational studied have reported an increase in T1N after the 2009 H1N1 pandemic [58]. A significantly increased risk of narcolepsy in adults and children was also linked to Pandemrix vaccination (influenza inactivated vaccine) [59,60]. Interestingly, the use of Focetria vaccination (differently formulated inactivated influenza vaccine) was not associated with increased T1N risk [61]. Considering the difference in the adjuvants as well as the antigens of both vaccines, as Pandemrix is a split-influenza vaccine while Focetria is a subunit vaccine resulting in distinct antigen formulations, 
this highlights the significant contribution of viral antigen composition in the development of autoimmunity [62].

Molecular mimicry of IAV antigens has been strongly suggested in $\mathrm{T} 1 \mathrm{~N}$, in which a similarity between H1N1 specific peptides and HCRT peptides was reported. In a very recent study, Luo et al. reported that sequences of $\mathrm{T}$ cell receptor (TCR) $\alpha$ and $\beta /$ complementarity-determining region (CDR) 3 were found in influenza HA nucleoprotein (NP) and HCRT tetramer-positive CD4+ T-cells, and also retrieved in INF- $\gamma$-secreting CD4+ T-cells stimulated with Pandemrix [57]. Accordingly, cross-reactivity between HCRT autoantigen and specific influenza sequences might explain how influenza infection or vaccine trigger T1N autoimmunity. Not only that, these findings also suggested the possible involvement of antigen spreading and CD8+ T-cells killing of HCRT neurons leading to this disorder, which is a known mechanism reported in other IAV-induced autoimmune disorders as well, including diabetes [63]. Nonetheless, to confirm these observations, sequence analysis of more TCRs in autoimmune responses is required.

Collectively, influenza-induced autoimmunity is explained by several mechanisms. In diabetes, the contribution of $\mathrm{T}$ cells bystander activation and direct beta cell damage are strongly supported. Nonetheless, in other autoimmune disorders such as T1N, molecular mimicry is believed to be the reason for disease initiation. Despite these findings, additional mechanistic and epidemiologic studies are necessary to investigate the occurrence of autoimmune disorders following influenza pandemics

\subsection{Herpesviruses}

There is an increasing evidence linking infection with herpesviruses to the development of multiple autoimmune disorders. Large epidemiological studies suggested that susceptibility to multiple sclerosis (MS) is gained in early childhood, with viral infections acting as a trigger. Consequently, herpesviruses which are a childhood infections, are considered appropriate candidates contributing to MS development [64]. Herpesviruses also persist in the host as a latent infection, and when reactivated contribute to disease pathogenesis as observed in systemic autoimmune diseases (SADs) $[65,66]$.

Epstein-Barr virus (EBV) infection is suspected to have a central role in the pathogenesis of SADs [66]. In fact, high viral loads of EBV DNA were detected in the blood of systemic lupus erythematosus (SLE) patients $[67,68]$. Furthermore, increased EBV viral mRNAs expression was reported in SLE patients [69]. Other reports linked SLE to EBV based on serological analysis. High titers of anti-early antigen (EA) IgG and IgA were found in SLE patients compared to healthy EBV carriers [65,70]. Increased EBV viral load, high titers of EBV antibodies, and abnormal cell-mediated immunity to EBV have been also observed in rheumatoid arthritis (RA) and Sjögren's syndrome (SS) patients [65]. These findings bear immediate relevance for the abnormal cell-mediated regulation of EBV infection and frequent virus reactivation that has been observed in RA, SS, and SLE patients [65].

EBV-mediated autoimmunity can also be developed through molecular mimicry, in which antibodies against EBV nuclear antigen 1 (EBNA1) cross-react with lupus associated autoantigens in SLE patients, followed by epitope spreading mechanism which will include more autoantigens [71]. Moreover, through TLR3 signaling, EBV infection induces the activation of innate immunity, and the production of type-I IFN and proinflammatory cytokines [72]. Inflammation in turn is known to contribute to autoreactivity enhancement and initiation of bystander activation [4]. Additionally, it has been found that some EBV proteins that are important in immune evasion and anti-apoptosis, such as early antigen restricted (EA/R), are homologues to cellular proteins such as Bcl2. Accordingly, this prevents both infected B cells and epithelial cells from apoptosis, and lead to a loss of tolerance and development of autoimmunity [66].

Herpesviruses are neurotropic and neurovirulent, which means they can infect cells of the central nervous system (CNS) and produce neurological illness. Of note, the eye and the CNS are immune privileged sites where the self-antigens of these organs are segregated from the adaptive immune system, in part via the blood brain barrier. Inflammation at these sites may lead to the loss of this barrier function, allowing immune cell infiltration. Herpesviruses-triggered MS can be mediated 
through direct lyses of CNS cells, or by the immunopathogenic host immune responses, increasing the pool of CNS specific self-antigens [64]. Several reports have indicated the presence of Herpes simplex virus (HSV) in active plaques from postmortem brain samples of MS patients [73]. In addition, it was found that the viral gene products following HSV-1 infection drive apoptosis in neuronal progenitor cells [74]. EBV, another herpesvirus that causes infectious mononucleosis (IM) has also been linked to MS [75]. Moreover, human herpesvirus 6 (HHV-6) was found to be more prevalent in MS plaques than normal MS white matter, and its reactivation has been observed in MS relapse [64]. Infection with HSV have been well-linked to herpetic stromal keratitis (HSK), which is an autoimmune corneal disease [1]. It was reported that molecular mimicry is involved in disease pathology for these viruses as well. Cornea-specific T-cell clones are found to recognize the HSV-1-derived protein UL6 in a murine model [5]. Contrarily, other studies showed that isolated T cells from HSK patients' corneas do no cross react with UL6, suggesting that T cells may induce pathogenesis through bystander destruction in humans [76]. In addition, earlier studies reported cytomegalovirus (CMV) genome in type 1 diabetes patients [77]. Also, persistent CMV infection was found to be associated with the induction of antibodies against islet cells [78]. Further, gastrointestinal and herpes viral infections have been linked to the induction of celiac disease (CD), which is a life-long autoimmune disorder [3,79].

In contrast to the aforementioned studies, interestingly, some other reports have shown a protective association between herpesviruses infections and autoimmunity $[3,80,81]$. Serum antibodies to CMV, EBV were found to be lower in CD patients compared to healthy controls [81]. Jansen et al., found that anti-CMV, EBV, and or HSV-1 IgG levels were inversely correlated with transglutaminase type 2 antibody (TG2A) levels, suggesting a protective impact of these viruses in the pathogenesis of CD $[82,83]$. The protective role of infections in autoimmunity supports the "hygiene hypothesis", which proposes that cleaner living environment leads to higher incidence of autoimmune disorders [80]. Lerner et al. found that higher CD incidences are correlated with less infectious environment [3]. Infections can abrogate autoimmunity disorders through several pathways including: post-translational modification of proteins (PTMP) form non-self to self, and therefore reducing their pathogenicity. For example, some microbial agents modify gluten and thus preventing intestine damage $[3,84]$. Additionally, some infections are able to shift the immune response from Th1 to Th2, establishing an immunosuppressive state in Th1-derived immune diseases, such as CD [80]. In fact, this protective effect has also been observed in parasitic infections. In mouse model, it was reported that helminths modulate the immune system and generate a Th2 environment, which protects from autoimmune diseases or relieve symptoms of established autoimmune inflammation [85]. Similarly, it was found that MS patients who are infected with helminth parasites have less severe disease compared to uninfected patients [86]. Interestingly, the administration of anti-helminthic drugs increased MS-associated disease activity [87]. Currently, the use of live helminths to treat MS and other AIDs is under clinical evaluation [88]. Other than immune system modulation towards Th2, viral infections, including infections produced by CMV and EBV, can cause apoptosis of the immune cells, thus, attenuating the immune system response, and minimizing autoimmune disease progression [3].

To summarize, the mechanisms by which herpesviruses trigger autoimmunity are variable. Both, molecular mimicry and bystander activation were reported in EBV- and HSV- induced autoimmunity. Not only that, EBV also has the ability to immortalize autoreactive infected B cells. In addition, as neurotropic viruses, herpesviruses can infect and kill CNS cells directly, leading to several AIDs.

\subsection{Other Viruses}

Infections with multiple other viruses such as measles and mumps (Paramyxoviridae family), and rubella (Togaviridae family), have been linked to autoimmune disorders. Specifically, mumps and rubella infections were linked to the onset of type 1 diabetes [89]. Both viruses have the ability to infect and grow in beta cells [90,91]. Further, both viruses result in CNS demyelination disease [64]. Viruses from the Flaviviridae family, such as Zika virus (ZIKV) and dengue virus (DENV) have been also associated to autoimmune disorders, including the recently reported ZIKV-induced Guillain-Barré 
syndrome and DENV-induced SLE and lupus nephritis [92,93]. Human T-lymphotropic virus type 1 (HTLV-1) from the Retroviridae family has been associated with CNS autoimmunity, causing myelopathy/tropical spastic paraparesis [9]. Several recent studies aimed to explain the contribution of viral infections in CNS disorders. It was suggested that antiviral immune response cross-react with human NMDA receptors (2A subunit) [94], which are responsible for excitatory glutamatergic transmission and are ion channel proteins found in nerve cells [95]. Pentapeptide similarity between the NMDA 2A receptor and viral proteins have been previously reported [96]. Using the same mechanism, other peptide commonalities with high degree of pentapeptide sharing were found between viral peptides and the human distal-less homeobox (DLX) transcription factors expressed during early fetal neurodevelopment (DLX1, DLX2, DLX5, and DLX6) [94]. Analysis of the brain-specific DLX self-antigens pentapeptide revealed matching with several viruses that have been related to neurological disorders including rubella and herpesviruses [94]. Collectively, these studies support the assumption that viral infections may relate to CNS disorders through autoimmune cross-reactions caused by molecular mimicry.

In a recent work by Kanduc, peptide sharing analysis of five common viruses (Borna disease virus, IAV, measles, mumps, and rubella) in comparison to human proteome revealed an unexpected massive viral human peptide cross-reactivity [97]. The author explained this finding in the light of the viral eukaryogenesis hypothesis, which describes that the first eukaryotic cell had evolved from an archaeal ancestor of the eukaryotic cytoplasm, a bacterial ancestor of the mitochondria, and a viral ancestor of the nucleus. Importantly, the clinical implication of this high viral/human peptide sequence similarity confirms the significant contribution of molecular mimicry as a mechanism in viral induced autoimmunity.

Considering the available data from epidemiological and experimental animal studies, there is a wide range of viruses that are suspected to initiate an autoimmune response, despite the lack of a clear mechanistic explanation to this phenomenon in most of the cases. Table 1 summarizes studies reporting viral induced autoimmunity in different organisms along with proposed mechanisms. Importantly, it is clear that there is no single factor responsible for triggering autoimmunity. It seems that the development of autoimmune diseases following viral infections is a multifactorial process that can be affected by different variables. Moreover, determining whether viral infection can lead to autoimmunity or protect from certain immune disorders such as diabetes [98] and CD [81], depends on multiple factors, including virus strain, genetic predisposition, host immune response, infectious dose, and time of infection [99].

Table 1. Examples of viral infections that have been linked to autoimmune diseases in different organisms.

\begin{tabular}{|c|c|c|c|c|}
\hline Autoimmune Disease & Virus & Organism & $\begin{array}{c}\text { Proposed } \\
\text { Mechanism }\end{array}$ & Study \\
\hline $\begin{array}{l}\text { Acute disseminated } \\
\text { encephalomyelitis }\end{array}$ & Influenza & Homo sapiens & $\begin{array}{c}\text { Bystander } \\
\text { activation \& } \\
\text { molecular mimicry }\end{array}$ & $\begin{array}{c}\text { Sanderson et al., } 2017 \\
\text { [100] }\end{array}$ \\
\hline $\begin{array}{l}\text { Autoantibodies in } \\
\text { acquired } \\
\text { immunodeficiency } \\
\text { syndrome }\end{array}$ & $\begin{array}{c}\text { Human } \\
\text { Immunodeficiency } \\
\text { virus }\end{array}$ & Homo sapiens & $\begin{array}{l}\text { Bystander } \\
\text { activation }\end{array}$ & $\begin{array}{l}\text { Root-Bernstein et al., } \\
2017 \text { [101] }\end{array}$ \\
\hline $\begin{array}{c}\text { Autoimmune } \\
\text { demyelinating disease }\end{array}$ & Semliki forest virus & Mus musculus & - & $\begin{array}{c}\text { Mokhtarian et al., } 2012 \\
\text { [102] }\end{array}$ \\
\hline $\begin{array}{l}\text { Autoimmune } \\
\text { encephalitis }\end{array}$ & Herpes simplex virus & Homo sapiens & Molecular mimicry & $\begin{array}{c}\text { Bradshaw et al., } 2015 \\
\text { [103] }\end{array}$ \\
\hline Autoimmune hepatitis & Esptein-Barr virus & Homo sapiens & Molecular mimicry & Cabibi et al., 2008 [104] \\
\hline $\begin{array}{l}\text { Autoimmune } \\
\text { myocarditis }\end{array}$ & Coxsackie virus & Mus musculus & - & $\begin{array}{c}\text { Fairweather and Rose, } \\
2007[105]\end{array}$ \\
\hline
\end{tabular}


Table 1. Cont.

\begin{tabular}{|c|c|c|c|c|}
\hline Autoimmune Disease & Virus & Organism & $\begin{array}{c}\text { Proposed } \\
\text { Mechanism }\end{array}$ & Study \\
\hline $\begin{array}{l}\text { Autoimmune } \\
\text { myocarditis }\end{array}$ & Coxsackievirus B3 & Mus musculus & $\begin{array}{l}\text { Bystander } \\
\text { activation }\end{array}$ & Rose, 2011 [106] \\
\hline Autoimmune thyroiditis & $\begin{array}{c}\text { Human herpesvirus } \\
6 \mathrm{~A}(\mathrm{HHV}-6 \mathrm{~A})\end{array}$ & Homo sapiens & - & Caselli et al., 2017 [107] \\
\hline Cryoglobulinemia & Hepatitis $C$ virus & Homo sapiens & - & Ogishi et al., 2016 [108] \\
\hline $\begin{array}{l}\text { Encephalitis (Human } \\
\text { herpes encephalitis) }\end{array}$ & Herpes simplex virus & Homo sapiens & Molecular mimicry & $\begin{array}{c}\text { Armangue et al., } 2014 \\
\text { [109] }\end{array}$ \\
\hline $\begin{array}{l}\text { Encephalitis and chronic } \\
\text { neurological sequelae }\end{array}$ & Herpes simplex virus & Homo sapiens & - & $\begin{array}{c}\text { Kothur et al., } 2017 \\
\text { [110] }\end{array}$ \\
\hline $\begin{array}{l}\text { Encephalitis, myasthenia } \\
\text { gravis }\end{array}$ & $\begin{array}{l}\text { Japenese encephalitis } \\
\text { virus }\end{array}$ & Mus musculus & Molecular mimicry & He et al., 2018 [111] \\
\hline $\begin{array}{l}\text { Experimental } \\
\text { autoimmune } \\
\text { encephalomyelitis }\end{array}$ & $\begin{array}{c}\text { Murine } \\
\text { Gamma-Herpesvirus } \\
68\end{array}$ & Mus musculus & - & $\begin{array}{c}\text { Casiraghi et al., } 2015 \\
\text { [112] }\end{array}$ \\
\hline Grave's disease & Esptein-Barr virus & Homo sapiens & - & $\begin{array}{c}\text { Nagata et al., } 2017 \\
{[113]}\end{array}$ \\
\hline Guillain-Barré syndrome & Zika virus & Homo sapiens & Molecular mimicry & $\begin{array}{c}\text { Lucchese and Kanduc, } \\
2016 \text { [114] }\end{array}$ \\
\hline Hashimoto's disease & Esptein-Barr virus & Homo sapiens & - & $\begin{array}{c}\text { Janegova et al., } 2015 \\
\text { [115] }\end{array}$ \\
\hline $\begin{array}{l}\text { Immune } \\
\text { thrombocytopenia, } \\
\text { autoimmune hepatitis }\end{array}$ & Hepatitis $C$ virus & Homo sapiens & - & $\begin{array}{c}\text { Tampaki and Koskinas, } \\
2014 \text { [116] }\end{array}$ \\
\hline Encephalomyelitis & Coronavirus & Mus musculus & - & $\begin{array}{l}\text { Pewe and Perlman, } \\
2002[117]\end{array}$ \\
\hline Induced type 1 diabetes & $\begin{array}{l}\text { Encephalomyocarditis-D } \\
\text { virus }\end{array}$ & Mus musculus & Molecular mimicry & Choi et al., 2001 [118] \\
\hline Islet autoimmunity & Enteroviruses & Homo sapiens & Molecular mimicry & $\begin{array}{c}\text { Honkanen et al., } 2017 \\
\text { [119] }\end{array}$ \\
\hline $\begin{array}{l}\text { Lung-restricted } \\
\text { autoimmunity }\end{array}$ & Sendai virus & Mus musculus & - & Chiu et al., 2016 [120] \\
\hline Multiple sclerosis & Esptein-Barr virus & Homo sapiens & Molecular mimicry & Guan et al., 2019 [121] \\
\hline Multiple sclerosis & Theiler's virus & Homo sapiens & - & Miller et al., 2001 [122] \\
\hline Multiple sclerosis & Varicella-zoster virus & Homo sapiens & - & $\begin{array}{c}\text { Sotelo and Corona, } \\
2011 \text { [123] }\end{array}$ \\
\hline Multiple sclerosis & Measles virus & Homo sapiens & - & $\begin{array}{c}\text { Tucker and Andrew } \\
\text { Paskauskas, } 2008 \text { [124] }\end{array}$ \\
\hline Multiple sclerosis & Cytomegalovirus & Homo sapiens & Molecular mimicry & $\begin{array}{c}\text { Vanheusden et al., } 2017 \\
\text { [125] }\end{array}$ \\
\hline Myasthenia gravis & West Nile virus & $\begin{array}{l}\text { Homo sapiens/Mus } \\
\text { musculus }\end{array}$ & Molecular mimicry & $\begin{array}{l}\text { McBride et al., } 2006 \\
\text { [126] }\end{array}$ \\
\hline $\begin{array}{l}\text { Myelopathy/tropical } \\
\text { spastic paraparesis }\end{array}$ & $\begin{array}{c}\text { Human } \\
\text { T-lymphotropic virus } \\
\text { type } 1\end{array}$ & Homo sapiens & - & $\begin{array}{c}\text { Bangham et al., } 2015 \\
\text { [127] }\end{array}$ \\
\hline Polyarthritis & Hepatitis $C$ virus & Homo sapiens & - & $\begin{array}{c}\text { Zuckerman et al., } 2000 \\
\text { [128] }\end{array}$ \\
\hline Pulmonary Fibrosis & Gammaherpesvirus & Mus musculus & - & $\begin{array}{l}\text { Bennion et al., } 2019 \\
\text { [129] }\end{array}$ \\
\hline Rheumatoid arthritis & Esptein-Barr virus & Homo sapiens & Epitope spreading & $\begin{array}{c}\text { Dostál C et al., } 1997 \\
\text { [130] }\end{array}$ \\
\hline Rheumatoid arthritis & Cytomegalovirus & Homo sapiens & Epitope spreading & Pera et al., 2017 [131] \\
\hline
\end{tabular}


Table 1. Cont

\begin{tabular}{|c|c|c|c|c|}
\hline Autoimmune Disease & Virus & Organism & $\begin{array}{c}\text { Proposed } \\
\text { Mechanism }\end{array}$ & Study \\
\hline $\begin{array}{c}\text { Pulmonary } \\
\text { inflammation in } \\
\text { lupus-prone mice }\end{array}$ & Influenza A virus & Mus musculus & $\begin{array}{c}\text { Bystander } \\
\text { activation \& } \\
\text { epitope spreading }\end{array}$ & $\begin{array}{c}\text { Slight-Webb et al., } 2015 \\
\text { [132] }\end{array}$ \\
\hline Sjogren syndrome & Hepatitis $C$ virus & Homo sapiens & $\begin{array}{l}\text { Bystander } \\
\text { activation }\end{array}$ & $\begin{array}{l}\text { Ramos-Casals et al., } \\
2005 \text { [133] }\end{array}$ \\
\hline Stromal keratitis & Herpes simplex virus & Homo sapiens & - & $\begin{array}{c}\text { Deshpande et al., } 2001 \\
\text { [134] }\end{array}$ \\
\hline Stromal keratitis & Herpes simplex virus & Homo sapiens & - & $\begin{array}{l}\text { Farooq and Shukla, } \\
2012 \text { [135] }\end{array}$ \\
\hline Symmetric polyarthritis & Chikungunya virus & Homo sapiens & Epitope spreading & $\begin{array}{c}\text { Goupil and Mores, } \\
2016[136]\end{array}$ \\
\hline $\begin{array}{l}\text { Systemic lupus } \\
\text { erythematosus }\end{array}$ & Cytomegalovirus & Homo sapiens & Epitope spreading & Chen et al., 2015 [137] \\
\hline $\begin{array}{l}\text { Systemic lupus } \\
\text { erythematosus in } \\
\text { porphyria cutanea tarda }\end{array}$ & Hepatitis $C$ virus & Homo sapiens & Epitope spreading & Stölzel et al., 2002 [138] \\
\hline $\begin{array}{l}\text { Systemic lupus } \\
\text { erythematous }\end{array}$ & $\underline{\text { Parvovirus B19 }}$ & Homo sapiens & - & $\begin{array}{c}\text { Ribeiro et al., } 2015 \\
\text { [139] }\end{array}$ \\
\hline $\begin{array}{c}\text { Systemic lupus } \\
\text { erythematous, lupus } \\
\text { nephritis }\end{array}$ & Dengue virus & Homo sapiens & Epitope spreading & $\begin{array}{c}\text { Steed and Stappenbeck, } \\
2014[140]\end{array}$ \\
\hline Systemic Vasculitis & Lassa Virus & $\begin{array}{l}\text { Cynomolgus } \\
\text { Macaques }\end{array}$ & - & $\begin{array}{c}\text { Cashman et al., } 2018 \\
\text { [141] }\end{array}$ \\
\hline Thrombocytopenia & Hepatitis $C$ virus & Homo sapiens & - & Dahal et al., 2017 [142] \\
\hline Thyroiditis & Hepatitis C virus & Homo sapiens & $\begin{array}{l}\text { Bystander } \\
\text { activation }\end{array}$ & Ferri et al., 2017 [143] \\
\hline $\begin{array}{c}\text { TMEV-induced } \\
\text { demyelinating disease }\end{array}$ & $\begin{array}{c}\text { Theiler's murine } \\
\text { encephalomyelitis } \\
\text { virus }\end{array}$ & Mus musculus & Molecular mimicry & $\begin{array}{c}\text { Olsberg et al., } 1993 \\
\text { [144] }\end{array}$ \\
\hline Type 1 diabetes mellitus & Coxsackievirus & Homo sapiens & Molecular mimicry & $\begin{array}{l}\text { Eizirik and Op de } \\
\text { Beeck, } 2018 \text { [145] }\end{array}$ \\
\hline Type 1 diabetes mellitus & Coxsackievirus B1 & Homo sapiens & Molecular mimicry & $\begin{array}{l}\text { Laitinen et al., } 2014 \\
\text { [146] }\end{array}$ \\
\hline Type 1 diabetes mellitus & Cytomegalovirus & Homo sapiens & & Pak et al., 1988 [77] \\
\hline Type 1 diabetes mellitus & Rotavirus & Mus musculus & Bystander effect & Pane et al., 2014 [41] \\
\hline Type 1 diabetes mellitus & Enteroviruses & $\begin{array}{l}\text { Homo sapiens/Mus } \\
\text { musculus }\end{array}$ & - & $\begin{array}{c}\text { Stene and Rewers, } 2012 \\
\text { [147] }\end{array}$ \\
\hline Vasculitis & Hepatitis $C$ virus & Homo sapiens & - & $\begin{array}{c}\text { Cacoub et al., } 2014 \\
\text { [148] }\end{array}$ \\
\hline
\end{tabular}

\section{Conclusions}

Viral infections are a major trigger of autoimmunity. Virus-induced autoimmunity is a multidirectional process. Current data suggests that viruses can initiate autoimmunity via several pathways including molecular mimicry, epitope spreading, bystander activation and/or immortalization of infected B cells. To the contrary, a growing evidence is supporting the protective role of viruses against autoimmunity [3], where viral infections lead to the activation of regulatory immune responses, consequently suppressing the development of autoimmune reactions. This dual effect of viral infections on autoimmunity is orchestrated by different host, viral and environmental factors. Accordingly, further epidemiological and molecular research is needed to gain insights about the interplay between viral infections and host autoimmune responses, and to provide a clear mechanistic description on how a viral infection can trigger autoimmunopathies. 
Author Contributions: H.M.Y. and M.K.S. conceived and designed the study. M.K.S. wrote the first draft of the manuscript. R.O.A. summarized the findings in a table. F.S.C., G.K.N., and A.A.A. proofread and revised the manuscript.

Acknowledgments: This work was supported by QNRF grant No. NPRP11S-1212-170092, and Qatar University Internal Grant No. QUCG-BRC-2018/2019-1.

Conflicts of Interest: The authors declare that the research was conducted in the absence of any commercial or financial relationships that could be construed as a potential conflict of interest.

\section{References}

1. Ercolini, A.M.; Miller, S.D. The role of infections in autoimmune disease. Clin. Exp. Immunol. 2009, 155, 1-15. [CrossRef]

2. Arleevskaya, M.I.; Manukyan, G.; Inoue, R.; Aminov, R. Editorial: Microbial and Environmental Factors in Autoimmune and Inflammatory Diseases. Front. Immunol. 2017, 8, 243. [CrossRef] [PubMed]

3. Lerner, A.; Arleevskaya, M.; Schmiedl, A.; Matthias, T. Microbes and Viruses Are Bugging the Gut in Celiac Disease. Are They Friends or Foes? Front. Microbiol. 2017, 8, 1392. [CrossRef] [PubMed]

4. Kim, B.; Kaistha, S.D.; Rouse, B.T. Viruses and autoimmunity. Autoimmunity 2006, 39, 71-77. [CrossRef] [PubMed]

5. Zhao, Z.; Granucci, F.; Yeh, L.; Schaffer, P.A.; Cantor, H. Molecular Mimicry by Herpes Simplex Virus-Type 1: Autoimmune Disease After Viral Infection. Science 1998, 279, 1344-1347. [CrossRef] [PubMed]

6. Coppieters, K.T.; Wiberg, A.; Von Herrath, M.G. Viral infections and molecular mimicry in type 1 diabetes. APMIS 2012, 120, 941-949. [CrossRef] [PubMed]

7. Gauntt, C.J.; Arizpe, H.M.; Higdon, A.L.; Wood, H.J.; Bowers, D.F.; Rozek, M.M.; Crawley, R. Molecular mimicry, anti-coxsackievirus B3 neutralizing monoclonal antibodies, and myocarditis. J. Immunol. 1995, 154, 2983-2995. [PubMed]

8. Croxford, J.; Olson, J.K.; Miller, S.D. Epitope spreading and molecular mimicry as triggers of autoimmunity in the Theiler's virus-induced demyelinating disease model of multiple sclerosis. Autoimmun. Rev. 2002, 1, 251-260. [CrossRef]

9. Getts, D.R.; Chastain, E.M.L.; Terry, R.L.; Miller, S.D. Virus infection, antiviral immunity, and autoimmunity. Immunol. Rev. 2013, 255, 197-209. [CrossRef]

10. Fujinami, R.S.; Von Herrath, M.G.; Christen, U.; Whitton, J.L. Molecular Mimicry, Bystander Activation, or Viral Persistence: Infections and Autoimmune Disease. Clin. Microbiol. Rev. 2006, 19, 80-94. [CrossRef]

11. Constantinescu, C.S.; Farooqi, N.; O’Brien, K.; Gran, B. Experimental autoimmune encephalomyelitis (EAE) as a model for multiple sclerosis (MS). Br. J. Pharmacol. 2011, 164, 1079-1106. [CrossRef] [PubMed]

12. Leis, A.A.; Szatmary, G.; Ross, M.A.; Stokic, D.S. West nile virus infection and myasthenia gravis. Muscle Nerve 2014, 49, 26-29. [CrossRef] [PubMed]

13. Miller, S.D.; VanderLugt, C.L.; Begolka, W.S.; Pao, W.; Yauch, R.L.; Neville, K.L.; Katz-Levy, Y.; Carrizosa, A.; Kim, B.S. Persistent infection with Theiler's virus leads to CNS autoimmunity via epitope spreading. Nat. Med. 1997, 3, 1133-1136. [CrossRef] [PubMed]

14. Nanbo, A.; Inoue, K.; Adachi-Takasawa, K.; Takada, K. Epstein-Barr virus RNA confers resistance to interferon-alpha-induced apoptosis in Burkitt's lymphoma. EMBO J. 2002, 21, 954-965. [CrossRef] [PubMed]

15. Filippi, C.M.; von Herrath, M.G. Viral trigger for type 1 diabetes: Pros and cons. Diabetes 2008, 57, $2863-2871$. [CrossRef] [PubMed]

16. Gamble, D.R.; Taylor, K.W. Seasonal Incidence of Diabetes Mellitus. Br. Med. J. 1969, 3, 631-633. [CrossRef]

17. Bergamin, C.S.; Dib, S.A. Enterovirus and type 1 diabetes: What is the matter? World J. Diabetes 2015, 6, 828-839. [CrossRef] [PubMed]

18. Sarmiento, L.; Cubas-Dueñas, I.; Cabrera-Rode, E. Evidence of association between type 1 diabetes and exposure to enterovirus in Cuban children and adolescents. MEDICC Rev. 2013, 15, 29-32. [CrossRef] [PubMed]

19. Hyoty, H.; Hiltunen, M.; Knip, M.; Laakkonen, M.; Vähäsalo, P.; Karjalainen, J.; Koskela, P.; Roivainen, M.; Leinikki, P.; Hovi, T.; et al. A Prospective Study of the Role of Coxsackie B and Other Enterovirus Infections in the Pathogenesis of IDDM. Diabetes 1995, 44, 652-657. [CrossRef] 
20. Kimpimäki, T.; Kupila, A.; Hämäläinen, A.M.; Kukko, M.; Kulmala, P.; Savola, K.; Simell, T.; Keskinen, P.; Ilonen, J.; Simell, O.; et al. The first signs of beta-cell autoimmunity appear in infancy in genetically susceptible children from the general population: The Finnish Type 1 Diabetes Prediction and Prevention Study. J. Clin. Endocrinol. Metab. 2001, 86, 4782-4788.

21. Lönnrot, M.; Korpela, K.; Knip, M.; Ilonen, J.; Simell, O.; Korhonen, S.; Savola, K.; Muona, P.; Simell, T.; Koskela, P.; et al. Enterovirus infection as a risk factor for beta-cell autoimmunity in a prospectively observed birth cohort: The Finnish Diabetes Prediction and Prevention Study. Diabetes 2000, 49, 1314-1318. [CrossRef] [PubMed]

22. Elshebani, A.; Olsson, A.; Westman, J.; Tuvemo, T.; Korsgren, O.; Frisk, G. Effects on isolated human pancreatic islet cells after infection with strains of enterovirus isolated at clinical presentation of type 1 diabetes. Virus Res. 2007, 124, 193-203. [CrossRef]

23. Oikarinen, M.; Tauriainen, S.; Honkanen, T.; Oikarinen, S.; Vuori, K.; Kaukinen, K.; Rantala, I.; Mäki, M.; Hyöty, H. Detection of enteroviruses in the intestine of type 1 diabetic patients. Clin. Exp. Immunol. 2008, 151, 71-75. [CrossRef] [PubMed]

24. Yeung, W.-C.G.; Rawlinson, W.D.; Craig, M.E. Enterovirus infection and type 1 diabetes mellitus: Systematic review and meta-analysis of observational molecular studies. BMJ 2011, 342, d35. [CrossRef]

25. Clements, G.; Galbraith, D.; Taylor, K. Coxsackie B virus infection and onset of childhood diabetes. Lancet 1995, 346, 221-223. [CrossRef]

26. Andréoletti, L.; Hober, D.; Hober-Vandenberghe, C.; Belaich, S.; Vantyghem, M.-C.; Lefebvre, J.; Wattré, P.; Hober-Vandenberghe, C.; Vantyghem, M. Detection of Coxsackie B Virus RNA sequences in whole blood samples from adult patients at the onset of type I diabetes mellitus. J. Med. Virol. 1997, 52, 121-127. [CrossRef]

27. Andréoletti, L.; Hober, D.; Hober-Vandenberghe, C.; Fajardy, I.; Belaich, S.; Lambert, V.; Vantyghem, M.C.; Lefebvre, J.; Wattre, P. Coxsackie B virus infection and beta cell autoantibodies in newly diagnosed IDDM adult patients. Clin. Diagn. Virol. 1998, 9, 125-133. [CrossRef]

28. Oikarinen, S.; Martiskainen, M.; Tauriainen, S.; Huhtala, H.; Ilonen, J.; Veijola, R.; Simell, O.; Knip, M.; Hyöty, H. Enterovirus RNA in blood is linked to the development of type 1 diabetes. Diabetes 2011, 60, 276-279. [CrossRef]

29. Juhela, S.; Hyoty, H.; Roivainen, M.; Härkönen, T.; Putto-Laurila, A.; Simell, O.; Ilonen, J. T-cell responses to enterovirus antigens in children with type 1 diabetes. Diabetes 2000, 49, 1308-1313. [CrossRef]

30. Yoon, J.W.; Austin, M.; Onodera, T.; Notkins, A.L. Isolation of a virus from the pancreas of a child with diabetic ketoacidosis. N. Engl. J. Med. 1979, 300, 1173-1179. [CrossRef]

31. Dotta, F.; Censini, S.; van Halteren, A.G.; Marselli, L.; Masini, M.; Dionisi, S.; Mosca, F.; Boggi, U.; Muda, A.O.; Del Prato, S.; et al. Coxsackie B4 virus infection of beta cells and natural killer cell insulitis in recent-onset type 1 diabetic patients. Proc. Natl. Acad. Sci. USA 2007, 104, 5115-5120. [CrossRef]

32. Pane, J.A.; Coulson, B.S. Lessons from the mouse: Potential contribution of bystander lymphocyte activation by viruses to human type 1 diabetes. Diabetologia 2015, 58, 1149-1159. [CrossRef]

33. Serreze, D.V.; Ottendorfer, E.W.; Ellis, T.M.; Gauntt, C.J.; Atkinson, M.A. Acceleration of type 1 diabetes by a coxsackievirus infection requires a preexisting critical mass of autoreactive T-cells in pancreatic islets. Diabetes 2000, 49, 708-711. [CrossRef]

34. Christen, U.; Wolfe, T.; Möhrle, U.; Hughes, A.C.; Rodrigo, E.; Green, E.A.; Flavell, R.A.; von Herrath, M.G. A dual role for TNF-alpha in type 1 diabetes: Islet-specific expression abrogates the ongoing autoimmune process when induced late but not early during pathogenesis. J. Immunol. 2001, 166, 7023-7032. [CrossRef]

35. Kaufman, D.L.; Erlander, M.G.; Clare-Salzler, M.; Atkinson, M.A.; MacLaren, N.K.; Tobin, A.J. Autoimmunity to two forms of glutamate decarboxylase in insulin-dependent diabetes mellitus. J. Clin. Investig. 1992, 89, 283-292. [CrossRef]

36. Hou, J.; Said, C.; Franchi, D.; Dockstader, P.; Chatterjee, N.K. Antibodies to Glutamic Acid Decarboxylase and P2-C Peptides in Sera from Coxsackie Virus B4-Infected Mice and IDDM Patients. Diabetes 1994, 43, 1260-1266. [CrossRef]

37. Yokota, I.; Shima, K. GAD antibody in IDDM. Rinsho. Byori. 1998, 46, 331-337.

38. Hansson, S.F.; Korsgren, S.; Pontén, F.; Korsgren, O. Enteroviruses and the pathogenesis of type 1 diabetes revisited: Cross-reactivity of enterovirus capsid protein (VP1) antibodies with human mitochondrial proteins. J. Pathol. 2013, 229, 719-728. [CrossRef] 
39. Casabonne, D.; Green, J.; Newton, R. Coxsackie B virus serology and Type 1 diabetes mellitus: A systematic review of published case-control studies. Diabet. Med. 2004, 21, 507-514.

40. Honeyman, M.C.; Coulson, B.S.; Stone, N.L.; Gellert, S.A.; Goldwater, P.N.; Steele, C.E.; Couper, J.J.; Tait, B.D.; Colman, P.G.; Harrison, L.C. Association between rotavirus infection and pancreatic islet autoimmunity in children at risk of developing type 1 diabetes. Diabetes 2000, 49, 1319-1324. [CrossRef]

41. Blomqvist, M.; Juhela, S.; Erkkilä, S.; Korhonen, S.; Simell, T.; Kupila, A.; Vaarala, O.; Simell, O.; Knip, M.; Ilonen, J. Rotavirus infections and development of diabetes-associated autoantibodies during the first 2 years of life. Clin. Exp. Immunol. 2002, 128, 511-515. [CrossRef]

42. Pane, J.A.; Webster, N.L.; Coulson, B.S. Rotavirus Activates Lymphocytes from Non-Obese Diabetic Mice by Triggering Toll-Like Receptor 7 Signaling and Interferon Production in Plasmacytoid Dendritic Cells. PLoS Pathog. 2014, 10, e1003998. [CrossRef]

43. Graham, K.L.; Sanders, N.; Tan, Y.; Allison, J.; Kay, T.W.H.; Coulson, B.S. Rotavirus Infection Accelerates Type 1 Diabetes in Mice with Established Insulitis. J. Virol. 2008, 82, 6139-6149. [CrossRef]

44. Pane, J.A.; Webster, N.L.; Graham, K.L.; Holloway, G.; Zufferey, C.; Coulson, B.S. Rotavirus acceleration of murine type 1 diabetes is associated with a T helper 1-dependent specific serum antibody response and virus effects in regional lymph nodes. Diabetologia 2013, 56, 573-582. [CrossRef]

45. Roman, L.M.; Simons, L.F.; Hammer, R.E.; Sambrook, J.F.; Gething, M.J. The expression of influenza virus hemagglutinin in the pancreatic beta cells of transgenic mice results in autoimmune diabetes. Cell 1990, 61, 383-396. [CrossRef]

46. Capua, I.; Mercalli, A.; Pizzuto, M.S.; Romero-Tejeda, A.; Kasloff, S.; De Battisti, C.; Bonfante, F.; Patrono, L.V.; Vicenzi, E.; Zappulli, V.; et al. Influenza A viruses grow in human pancreatic cells and cause pancreatitis and diabetes in an animal model. J. Virol. 2013, 87, 597-610. [CrossRef]

47. Likos, A.M.; Kelvin, D.J.; Cameron, C.M.; Rowe, T.; Kuehnert, M.J.; Norris, P.J. National Heart, Lung, Blood Institute Retrovirus Epidemiology Donor Study-II (REDS-II). Influenza viremia and the potential for blood-borne transmission. Transfusion 2007, 47, 1080-1088. [CrossRef]

48. Oughton, M.; Dascal, A.; LaPorta, D.; Charest, H.; Afilalo, M.; Miller, M. Evidence of viremia in 2 cases of severe pandemic influenza A H1N1/09. Diagn. Microbiol. Infect. Dis. 2011, 70, 213-217. [CrossRef]

49. Tan, H.; Wang, C.; Yu, Y. H1N1 Influenza: The Trigger of Diabetic Ketoacidosis in a Young Woman with Ketosis-Prone Diabetes. Am. J. Med. Sci. 2012, 343, 180-183. [CrossRef]

50. Watanabe, N. Conversion to type 1 diabetes after H1N1 influenza infection: A case report. J. Diabetes 2011, 3, 103. [CrossRef]

51. Nenna, R.; Papoff, P.; Moretti, C.; Pierangeli, A.; Sabatino, G.; Costantino, F.; Soscia, F.; Cangiano, G.; Ferro, V.; Mennini, M.; et al. Detection of Respiratory Viruses in the 2009 Winter Season in Rome: 2009 Influenza a (H1N1) Complications in Children and Concomitant Type 1 Diabetes Onset. Int. J. Immunopathol. Pharmacol. 2011, 24, 651-659. [CrossRef]

52. Lönnrot, M.; Lynch, K.F.; Larsson, H.E.; Lernmark, Å.; Rewers, M.J.; Törn, C.; Burkhardt, B.R.; Briese, T.; Hagopian, W.A.; She, J.X.; et al. Respiratory infections are temporally associated with initiation of type 1 diabetes autoimmunity: The TEDDY study. Diabetologia 2017, 60, 1931-1940. [CrossRef]

53. Ferreira, R.C.; Guo, H.; Coulson, R.M.; Smyth, D.J.; Pekalski, M.L.; Burren, O.S.; Cutler, A.J.; Doecke, J.D.; Flint, S.; McKinney, E.F.; et al. A Type I Interferon Transcriptional Signature Precedes Autoimmunity in Children Genetically at Risk for Type 1 Diabetes. Diabetes 2014, 63, 2538-2550. [CrossRef]

54. Xia, C.Q.; Peng, R.; Chernatynskaya, A.V.; Yuan, L.; Carter, C.; Valentine, J.; Sobel, E.; Atkinson, M.A.; Clare-Salzler, M.J. Increased IFN- $\alpha$-producing Plasmacytoid Dendritic Cells (pDCs) in Human Th1-mediated Type 1 Diabetes: pDCs Augment Th1 Responses through IFN- $\alpha$ Production1. J. Immunol. 2014, 193, 1024-1034. [CrossRef]

55. Zanker, D.J.; Oveissi, S.; Tscharke, D.C.; Duan, M.; Wan, S.; Zhang, X.; Xiao, K.; Mifsud, N.A.; Gibbs, J.; Izzard, L.; et al. Influenza A Virus Infection Induces Viral and Cellular Defective Ribosomal Products Encoded by Alternative Reading Frames. J. Immunol. 2019, 202, 3370-3380. [CrossRef]

56. Ahmed, S.S.; Volkmuth, W.; Duca, J.; Corti, L.; Pallaoro, M.; Pezzicoli, A.; Karle, A.; Rigat, F.; Rappuoli, R.; Narasimhan, V.; et al. Antibodies to influenza nucleoprotein cross-react with human hypocretin receptor 2. Sci. Transl. Med. 2015, 7, 294ra105. [CrossRef] 
57. Luo, G.; Ambati, A.; Lin, L.; Bonvalet, M.; Partinen, M.; Ji, X.; Maecker, H.T.; Mignot, E.J.M. Autoimmunity to hypocretin and molecular mimicry to flu in type 1 narcolepsy. Proc. Natl. Acad. Sci. USA 2018, 115, E12323-E12332. [CrossRef]

58. Han, F.; Lin, L.; Warby, S.C.; Faraco, J.; Li, J.; Dong, S.X.; An, P.; Zhao, L.; Wang, L.H.; Li, Q.Y.; et al. Narcolepsy onset is seasonal and increased following the 2009 H1N1 pandemic in china. Ann. Neurol. 2011, 70, 410-417. [CrossRef]

59. Stowe, J.; Andrews, N.; Kosky, C.; Dennis, G.; Eriksson, S.; Hall, A.; Leschziner, G.; Reading, P.; Shneerson, J.M.; Donegan, K.; et al. Risk of Narcolepsy after AS03 Adjuvanted Pandemic A/H1N1 2009 Influenza Vaccine in Adults: A Case-Coverage Study in England. Sleep 2016, 39, 1051-1057. [CrossRef]

60. Nohynek, H.; Jokinen, J.; Partinen, M.; Vaarala, O.; Kirjavainen, T.; Sundman, J.; Himanen, S.L.; Hublin, C.; Julkunen, I.; Olsén, P.; et al. AS03 adjuvanted AH1N1 vaccine associated with an abrupt increase in the incidence of childhood narcolepsy in Finland. PLoS ONE 2012, 7, e33536. [CrossRef]

61. Tsai, T.F. MF59 Adjuvanted Seasonal and Pandemic Influenza Vaccines. Yakugaku Zasshi 2011, 131, $1733-1741$. [CrossRef]

62. Update on Narcolepsy Cases Associated with Pandemrix Vaccination in 2009 in the Netherlands. Available online: https:/ecdc.europa.eu/en/news-events/update-narcolepsy-cases-associated-pandemrix-vaccination2009-netherlands (accessed on 21 March 2019).

63. Ahmed, S.S.; Steinman, L. Narcolepsy and influenza vaccination-induced autoimmunity. Ann. Transl. Med. 2017, 5, 25. [CrossRef]

64. Virtanen, J.O.; Jacobson, S. Viruses and multiple sclerosis. CNS Neurol. Disord. Drug Targets 2012, 11, 528-544. [CrossRef]

65. Draborg, A.H.; Duus, K.; Houen, G. Epstein-Barr Virus and Systemic Lupus Erythematosus. Clin. Dev. Immunol. 2012, 2012, 1-10. [CrossRef]

66. Draborg, A.H.; Duus, K.; Houen, G. Epstein-Barr Virus in Systemic Autoimmune Diseases. Clin. Dev. Immunol. 2013, 2013, 1-9. [CrossRef]

67. Yu, S.F.; Wu, H.C.; Tsai, W.C.; Yen, J.H.; Chiang, W.; Yuo, C.Y.; Lu, S.N.; Chiang, L.C.; Chen, C.J. Detecting Epstein-Barr virus DNA from peripheral blood mononuclear cells in adult patients with systemic lupus erythematosus in Taiwan. Med. Microbiol. Immunol. 2005, 194, 115-120. [CrossRef]

68. Moon, U.Y.; Park, S.J.; Oh, S.T.; Kim, W.U.; Park, S.H.; Lee, S.H.; Cho, C.S.; Kim, H.Y.; Lee, W.K.; Lee, S.K. Patients with systemic lupus erythematosus have abnormally elevated Epstein-Barr virus load in blood. Arthritis Res. Ther. 2004, 6, R295-R302. [CrossRef]

69. Gross, A.J.; Hochberg, D.; Rand, W.M.; Thorley-Lawson, D.A. EBV and Systemic Lupus Erythematosus: A New Perspective. J. Immunol. 2005, 174, 6599-6607. [CrossRef]

70. Draborg, A.; Jørgensen, J.; Muller, H.; Nielsen, C.; Jacobsen, S.; Iversen, L.; Theander, E.; Nielsen, L.; Houen, G.; Duus, K. Epstein-Barr virus early antigen diffuse (EBV-EA/D)-directed immunoglobulin A antibodies in systemic lupus erythematosus patients. Scand. J. Rheumatol. 2012, 41, 280-289. [CrossRef]

71. Poole, B.D.; Scofield, R.H.; Harley, J.B.; James, J.A. Epstein-Barr virus and molecular mimicry in systemic lupus erythematosus. Autoimmunity 2006, 39, 63-70. [CrossRef]

72. Iwakiri, D.; Zhou, L.; Samanta, M.; Matsumoto, M.; Ebihara, T.; Seya, T.; Imai, S.; Fujieda, M.; Kawa, K.; Takada, K. Epstein-Barr virus (EBV)-encoded small RNA is released from EBV-infected cells and activates signaling from Toll-like receptor 3. J. Exp. Med. 2009, 206, 2091-2099. [CrossRef]

73. Sanders, V.J.; Waddell, A.E.; Felisan, S.L.; Li, X.; Conrad, A.J.; Tourtellotte, W.W. Herpes Simplex Virus in Postmortem Multiple Sclerosis Brain Tissue. Arch. Neurol. 1996, 53, 125-133. [CrossRef]

74. Chucair-Elliott, A.J.; Conrady, C.; Zheng, M.; Kroll, C.M.; Lane, T.E.; Carr, D.J.J. Microglia-induced IL-6 protects against neuronal loss following HSV-1 infection of neural progenitor cells. Glia 2014, 62, 1418-1434. [CrossRef]

75. Lünemann, J.D. Epstein-Barr virus in multiple sclerosis: A continuing conundrum. Neurology 2012, 78, 11-12. [CrossRef]

76. Verjans, G.M.; Remeijer, L.; Mooy, C.M.; Osterhaus, A.D. Herpes simplex virus-specific T cells infiltrate the cornea of patients with herpetic stromal keratitis: No evidence for autoreactive T cells. Investig. Ophthalmol. Vis. Sci. 2000, 41, 2607-2612.

77. Pak, C.; McArthur, R.; Eun, H.M.; Yoon, J.W. Association of cytomegalovirus infection with autoimmune type 1 diabetes. Lancet 1988, 332, 1-4. [CrossRef] 
78. Rickinson, A.B.; Young, L.S.; Rowe, M. Influence of the Epstein-Barr virus nuclear antigen EBNA 2 on the growth phenotype of virus-transformed B cells. J. Virol. 1987, 61, 1310-1317.

79. Kemppainen, K.M.; Lynch, K.F.; Liu, E.; Lönnrot, M.; Simell, V.; Briese, T.; Koletzko, S.; Hagopian, W.; Rewers, M.; She, J.X.; et al. Factors That Increase Risk of Celiac Disease Autoimmunity after a Gastrointestinal Infection in Early Life. Clin. Gastroenterol. Hepatol. 2017, 15, 694-702. [CrossRef]

80. Christen, U.; Von Herrath, M.G. Infections and Autoimmunity-Good or Bad? J. Immunol. 2005, 174, 7481-7486. [CrossRef]

81. Plot, L.; Amital, H.; Barzilai, O.; Ram, M.; Nicola, B.; Shoenfeld, Y. Infections May Have a Protective Role in the Etiopathogenesis of Celiac Disease. Ann. N. Y. Acad. Sci. 2009, 1173, 670-674. [CrossRef]

82. Jansen, M.A.; van den Heuvel, D.; van der Zwet, K.V.; Jaddoe, V.W.; Hofman, A.; Escher, J.C.; Fraaij, P.L.; Hooijkaas, H.; van Zelm, M.C.; Moll, H.A. Herpesvirus Infections and Transglutaminase Type 2 Antibody Positivity in Childhood: The Generation R Study. J. Pediatr. Gastroenterol. Nutr. 2016, 63, 423-430. [CrossRef]

83. Jansen, M.A.; Beth, S.A.; Van Den Heuvel, D.; Kiefte-de Jong, J.C.; Raat, H.; Jaddoe, V.W.; van Zelm, M.C.; Moll, H.A. Ethnic differences in coeliac disease autoimmunity in childhood: The Generation R Study. Arch. Dis. Child. 2017, 102, 529-534. [CrossRef]

84. Caminero, A.; Galipeau, H.J.; McCarville, J.L.; Johnston, C.W.; Bernier, S.P.; Russell, A.K.; Jury, J.; Herran, A.R.; Casqueiro, J.; Tye-Din, J.A.; et al. Duodenal Bacteria from Patients With Celiac Disease and Healthy Subjects Distinctly Affect Gluten Breakdown and Immunogenicity. Gastroenterology 2016, 151, 670-683. [CrossRef]

85. Zandman-Goddard, G. Parasitic infection and autoimmunity. Lupus 2009, 18, 1144-1148. [CrossRef]

86. Correale, J.; Farez, M. Association between parasite infection and immune responses in multiple sclerosis. Ann. Neurol. 2007, 61, 97-108. [CrossRef]

87. Correale, J.; Farez, M.F. The impact of parasite infections on the course of multiple sclerosis. J. Neuroimmunol. 2011, 233, 6-11. [CrossRef]

88. Finlay, C.M.; Stefanska, A.M.; Walsh, K.P.; Kelly, P.J.; Boon, L.; Lavelle, E.C.; Walsh, P.T.; Mills, K.H. Helminth Products Protect against Autoimmunity via Innate Type 2 Cytokines IL-5 and IL-33, Which Promote Eosinophilia. J. Immunol. 2016, 196, 703-714. [CrossRef]

89. Ramondetti, F.; Sacco, S.; Comelli, M.; Bruno, G.; Falorni, A.; Iannilli, A.; d'Annunzio, G.; Iafusco, D.; Songini, M.; Toni, S.; et al. Type 1 diabetes and measles, mumps and rubella childhood infections within the Italian Insulin-dependent Diabetes Registry. Diabet. Med. 2012, 29, 761-766. [CrossRef]

90. Vuorinen, T.; Nikolakaros, G.; Smell, O.; Hyypiä, T.; Vainionpää, R. Mumps and Coxsackie B3 Virus Infection of Human Fetal Pancreatic Islet-like Cell Clusters. Pancreas 1992, 7, 460-464. [CrossRef]

91. Numazaki, K.; Goldman, H.; Seemayer, T.A.; Wong, I.; Wainberg, M.A. Infection by human cytomegalovirus and rubella virus of cultured human fetal islets of Langerhans. Vivo 1990, 4, 49-54.

92. Pinto-Díaz, C.A.; Rodríguez, Y.; Monsalve, D.M.; Acosta-Ampudia, Y.; Molano-González, N.; Anaya, J.M.; Ramírez-Santana, C. Autoimmunity in Guillain-Barré syndrome associated with Zika virus infection and beyond. Autoimmun. Rev. 2017, 16, 327-334. [CrossRef]

93. Talib, S.H.; Bhattu, S.; Bhattu, R.; Deshpande, S.; Dahiphale, D. Dengue fever triggering systemic lupus erythematosus and lupus nephritis: A case report. Int. Med Case Rep. J. 2013, 6, 71-75. [CrossRef]

94. Lucchese, G.; Stahl, B. Peptide Sharing Between Viruses and DLX Proteins: A Potential Cross-Reactivity Pathway to Neuropsychiatric Disorders. Front. Mol. Neurosci. 2018, 12, 150. [CrossRef]

95. Newcomer, J.W.; Farber, N.B.; Olney, J.W. NMDA receptor function, memory, and brain aging. Dialog. Clin. Neurosci. 2000, 2, 219-232.

96. Lucchese, G. Understanding Neuropsychiatric Diseases, Analyzing the Peptide Sharing between Infectious Agents and the Language-Associated NMDA 2A Protein. Front. Psychol. 2016, 7, 60. [CrossRef]

97. Kanduc, D. The comparative biochemistry of viruses and humans: An evolutionary path towards autoimmunity. Biol. Chem. 2019, 400, 629-638. [CrossRef]

98. Tracy, S.; Drescher, K.M.; Jackson, J.D.; Kim, K.; Kono, K. Enteroviruses, type 1 diabetes and hygiene: A complex relationship. Rev. Med Virol. 2010, 20, 106-116. [CrossRef]

99. Christen, U.; Von Herrath, M.G. Do viral infections protect from or enhance type 1 diabetes and how can we tell the difference? Cell. Mol. Immunol. 2011, 8, 193-198. [CrossRef]

100. Sanderson, N.S.R.; Zimmermann, M.; Eilinger, L.; Gubser, C.; Schaeren-Wiemers, N.; Lindberg, R.L.P.; Dougan, S.K.; Ploegh, H.L.; Kappos, L.; Derfuss, T. Cocapture of cognate and bystander antigens can activate autoreactive B cells. Proc. Natl. Acad. Sci. USA 2017, 114, 734-739. [CrossRef] 
101. Root-Bernstein, R. Human Immunodeficiency Virus Proteins Mimic Human T Cell Receptors Inducing Cross-Reactive Antibodies. Int. J. Mol. Sci. 2017, 18, 2091. [CrossRef]

102. Mokhtarian, F.; Safavi, F.; Sarafraz-Yazdi, E. Immunization with a peptide of Semliki Forest virus promotes remyelination in experimental autoimmune encephalomyelitis. Brain Res. 2012, 1488, 92-103. [CrossRef]

103. Bradshaw, M.J.; Pawate, S.; Lennon, V.A.; Bloch, K.C.; Brown, K.M. Herpes simplex virus 1 encephalitis associated with voltage-gated calcium channel autoimmunity. Neurology 2015, 85, 2176-2177. [CrossRef]

104. Cabibi, D. Autoimmune hepatitis following Epstein-Barr virus infection. BMJ Case Rep. 2008, 2008, bcr0620080071. [CrossRef]

105. Fairweather, D.; Rose, N.R. Coxsackievirus-induced myocarditis in mice: A model of autoimmune disease for studying immunotoxicity. Methods 2007, 41, 118-122. [CrossRef]

106. Rose, N.R. Critical Cytokine Pathways to Cardiac Inflammation. J. Interf. Cytokine Res. 2011, 31, 705-710. [CrossRef]

107. Caselli, E.; D'Accolti, M.; Soffritti, I.; Zatelli, M.C.; Rossi, R.; Degli Uberti, E.; Di Luca, D. HHV-6A in vitro infection of thyrocytes and $\mathrm{T}$ cells alters the expression of miRNA associated to autoimmune thyroiditis. Virol. J. 2017, 14, 3. [CrossRef]

108. Ogishi, M.; Yotsuyanagi, H.; Moriya, K.; Koike, K. Delineation of autoantibody repertoire through differential proteogenomics in hepatitis C virus-induced cryoglobulinemia. Sci. Rep. 2016, 6, 29532. [CrossRef]

109. Armangue, T.; Leypoldt, F.; Málaga, I.; Raspall-Chaure, M.; Martì, I.; Nichter, C.; Pugh, J.; Vicente-Rasoamalala, M.; Lafuente-Hidalgo, M.; Macaya, A.; et al. Herpes Simplex Virus Encephalitis is a Trigger of Brain Autoimmunity. Ann. Neurol. 2014, 75, 317-323. [CrossRef]

110. Kothur, K.; Gill, D.; Wong, M.; Mohammad, S.S.; Bandodkar, S.; Arbunckle, S.; Wienholt, L.; Dale, R.C. Cerebrospinal fluid cyto-/chemokine profile during acute herpes simplex virus induced anti- $N$-methyl-D -aspartate receptor encephalitis and in chronic neurological sequelae. Dev. Med. Child Neurol. 2017, 59, 806-814. [CrossRef]

111. He, D.; Zhang, H.; Xiao, J.; Zhang, X.; Xie, M.; Pan, D.; Wang, M.; Luo, X.; Bu, B.; Zhang, M.; et al. Molecular and clinical relationship between live-attenuated Japanese encephalitis vaccination and childhood onset myasthenia gravis. Ann. Neurol. 2018, 84, 386-400. [CrossRef]

112. Casiraghi, C.; Márquez, A.C.; Shanina, I.; Horwitz, M.S. Latent virus infection upregulates CD40 expression facilitating enhanced autoimmunity in a model of multiple sclerosis. Sci. Rep. 2015, 5, 13995. [CrossRef]

113. Nagata, K.; Kumata, K.; Nakayama, Y.; Satoh, Y.; Sugihara, H.; Hara, S.; Matsushita, M.; Kuwamoto, S.; Kato, M.; Murakami, I.; et al. Epstein-Barr Virus Lytic Reactivation Activates B Cells Polyclonally and Induces Activation-Induced Cytidine Deaminase Expression: A Mechanism Underlying Autoimmunity and Its Contribution to Graves' Disease. Viral Immunol. 2017, 30, 240-249. [CrossRef]

114. Lucchese, G.; Kanduc, D. Zika virus and autoimmunity: From microcephaly to Guillain-Barré syndrome, and beyond. Autoimmun. Rev. 2016, 15, 801-808. [CrossRef]

115. Janegova, A.; Janega, P.; Rychly, B.; Kuracinova, K.; Babal, P. The role of Epstein-Barr virus infection in the development of autoimmune thyroid diseases. Endokrynol. Pol. 2015, 66, 132-136. [CrossRef]

116. Tampaki, M.; Koskinas, J. Extrahepatic immune related manifestations in chronic hepatitis $C$ virus infection. World J. Gastroenterol. 2014, 20, 12372-12380. [CrossRef]

117. Pewe, L.; Perlman, S. Cutting edge: CD8 T cell-mediated demyelination is IFN-gamma dependent in mice infected with a neurotropic coronavirus. J. Immunol. 2002, 168, 1547-1551. [CrossRef]

118. Choi, K.S.; Jun, H.S.; Kim, H.N.; Park, H.J.; Eom, Y.W.; Noh, H.L.; Kwon, H.; Kim, H.M.; Yoon, J.W. Role of Hck in the Pathogenesis of Encephalomyocarditis Virus-Induced Diabetes in Mice. J. Virol. 2001, 75, 1949-1957. [CrossRef]

119. Honkanen, H.; Oikarinen, S.; Nurminen, N.; Huhtala, H.; Lehtonen, J.; Ruokoranta, T.; Lecouturier, V.; Tauriainen, S.; Ilonen, J.; Veijola, R.; et al. Detection of enteroviruses in stools precedes islet autoimmunity by several months: Possible evidence for slowly operating mechanisms in virus-induced autoimmunity. Diabetologia 2017, 60, 424-431. [CrossRef]

120. Chiu, S.; Fernandez, R.; Subramanian, V.; Sun, H.; DeCamp, M.M.; Kreisel, D.; Perlman, H.; Budinger, G.R.S.; Mohanakumar, T.; Bharat, A. Lung injury combined with loss of regulatory $\mathrm{T}$ cells leads to de novo lung-restricted autoimmunity. J. Immunol. 2016, 197, 51-57. [CrossRef] 
121. Guan, Y.; Jakimovski, D.; Ramanathan, M.; Weinstock-Guttman, B.; Zivadinov, R. The role of Epstein-Barr virus in multiple sclerosis: From molecular pathophysiology to in vivo imaging. Neural Regen. Res. 2019, 14, 373-386.

122. Miller, S.D.; Katz-Levy, Y.; Neville, K.L.; VanderLugt, C.L. Virus-induced autoimmunity: Epitope spreading to myelin autoepitopes in theiler's virus infection of the central nervous system. Adv Virus Res 2001, 56, 199-217.

123. Sotelo, J.; Corona, T. Varicella Zoster Virus and Relapsing Remitting Multiple Sclerosis. Mult. Scler. Int. 2011, 2011, 214763. [CrossRef]

124. Tucker, W.G.; Paskauskas, R.A. The MSMV hypothesis: Measles virus and multiple sclerosis, etiology and treatment. Med. Hypotheses 2008, 71, 682-689. [CrossRef]

125. Vanheusden, M.; Broux, B.; Welten, S.P.M.; Peeters, L.M.; Panagioti, E.; Van Wijmeersch, B.; Somers, V.; Stinissen, P.; Arens, R.; Hellings, N. Cytomegalovirus infection exacerbates autoimmune mediated neuroinflammation. Sci. Rep. 2017, 7, 663. [CrossRef]

126. McBride, W.; Gill, K.R.; Wiviott, L. West Nile Virus infection with hearing loss. J. Infect. 2006, 53, e203-e205. [CrossRef]

127. Bangham, C.R.M.; Araújo, A.; Yamano, Y.; Taylor, G.P. HTLV-1-associated myelopathy/tropical spastic paraparesis. Nat. Rev. Dis. Prim. 2015, 1, 15012. [CrossRef]

128. Zuckerman, E.; Keren, D.; Rozenbaum, M.; Toubi, E.; Slobodin, G.; Tamir, A.; Naschitz, J.E.; Yeshurun, D.; Rosner, I. Hepatitis C virus-related arthritis: Characteristics and response to therapy with interferon alpha. Clin. Exp. Rheumatol. 2000, 18, 579-584.

129. Bennion, B.G.; Ingle, H.; Ai, T.L.; Miner, C.A.; Platt, D.J.; Smith, A.M.; Baldridge, M.T.; Miner, J.J. A Human Gain-of-Function STING Mutation Causes Immunodeficiency and Gammaherpesvirus-Induced Pulmonary Fibrosis in Mice. J. Virol. 2019, 93, e01806-18. [CrossRef]

130. Dostál, C.; Newkirk, M.M.; Duffy, K.N.; Palecková, A.; Bosák, V.; Cerná, M.; Zd'arský, E.; Zvárová, J. Herpes viruses in multicase families with rheumatoid arthritis and systemic lupus erythematosus. Ann. N. Y. Acad. Sci. 1997, 815, 334-337. [CrossRef]

131. Pera, A.; Broadley, I.; Davies, K.A.; Kern, F. Cytomegalovirus as a Driver of Excess Cardiovascular Mortality in Rheumatoid Arthritis: A Red Herring or a Smoking Gun? Circ. Res. 2017, 120, 274-277. [CrossRef]

132. Slight-Webb, S.R.; Bagavant, H.; Crowe, S.R.; James, J.A. Influenza A (H1N1) Virus Infection Triggers Severe Pulmonary Inflammation in Lupus-Prone Mice following Viral Clearance. J. Autoimmun. 2015, 57, 66-76. [CrossRef]

133. Ramos-Casals, M.; Loustaud-Ratti, V.; De Vita, S.; Zeher, M.; Bosch, J.-A.; Toussirot, E.; Medina, F.; Rosas, J.; Anaya, J.-M.; Font, J. Sjögren syndrome associated with hepatitis C virus: A multicenter analysis of 137 cases. Medicine 2005, 84, 81-89. [CrossRef]

134. Deshpande, S.P.; Lee, S.; Zheng, M.; Song, B.; Knipe, D.; Kapp, J.A.; Rouse, B.T. Herpes Simplex Virus-Induced Keratitis: Evaluation of the Role of Molecular Mimicry in Lesion Pathogenesis. J. Virol. 2001, 75, 3077-3088. [CrossRef]

135. Farooq, A.V.; Shukla, D. Herpes Simplex Epithelial and Stromal Keratitis: An Epidemiologic Update. Surv. Ophthalmol. 2012, 57, 448-462. [CrossRef]

136. Goupil, B.A.; Mores, C.N. A Review of Chikungunya Virus-induced Arthralgia: Clinical Manifestations, Therapeutics, and Pathogenesis. Open Rheumatol. J. 2016, 10, 129-140. [CrossRef]

137. Chen, J.; Zhang, H.; Chen, P.; Lin, Q.; Zhu, X.; Zhang, L.; Xue, X. Correlation between systemic lupus erythematosus and cytomegalovirus infection detected by different methods. Clin. Rheumatol. 2015, 34, 691-698. [CrossRef]

138. Stölzel, U.; Schuppan, D.; Tillmann, H.L.; Manns, M.P.; Tannapfel, A.; Doss, M.O.; Zimmer, T.; Köstler, E. Autoimmunity and HCV infection in porphyria cutanea tarda: A controlled study. Cell. Mol. Biol. 2002, 48, $43-47$.

139. Ribeiro, F.M.; Gomez, V.E.; Albuquerque, E.M.; Klumb, E.M.; Shoenfeld, Y. Lupus and leprosy: Beyond the coincidence. Immunol. Res. 2015, 61, 160-163. [CrossRef]

140. Steed, A.L.; Stappenbeck, T.S. Role of Viruses and Bacteria-Virus Interactions in Autoimmunity. Curr. Opin. Immunol. 2014, 31, 102-107. [CrossRef] 
141. Cashman, K.A.; Wilkinson, E.R.; Zeng, X.; Cardile, A.P.; Facemire, P.R.; Bell, T.M.; Bearss, J.J.; Shaia, C.I.; Schmaljohn, C.S.; Garry, R.; et al. Immune-Mediated Systemic Vasculitis as the Proposed Cause of Sudden-Onset Sensorineural Hearing Loss following Lassa Virus Exposure in Cynomolgus Macaques. MBio 2018, 9. [CrossRef]

142. Dahal, S.; Upadhyay, S.; Banjade, R.; Dhakal, P.; Khanal, N.; Bhatt, V.R. Thrombocytopenia in Patients with Chronic Hepatitis C Virus Infection. Mediterr. J. Hematol. Infect. Dis. 2017, 9, e2017019. [CrossRef]

143. Ferri, C.; Colaci, M.; Fallahi, P.; Ferrari, S.M.; Antonelli, A.; Giuggioli, D. Thyroid Involvement in Hepatitis C Virus-Infected Patients with/without Mixed Cryoglobulinemia. Front. Endocrinol. 2017, 8, 159. [CrossRef]

144. Olsberg, C.; Pelka, A.; Miller, S.; Waltenbaugh, C.; Creighton, T.M.; Dal Canto, M.C.; Lipton, H.; Melvold, R. Induction of Theiler's murine encephalomyelitis virus (TMEV)-induced demyelinating disease in genetically resistant mice. Reg Immunol. 1993, 5, 1-10.

145. Eizirik, D.L.; De Beeck, A.O. Coxsackievirus and Type 1 Diabetes Mellitus: The Wolf's Footprints. Trends Endocrinol. Metab. 2018, 29, 137-139. [CrossRef]

146. Laitinen, O.H.; Honkanen, H.; Pakkanen, O.; Oikarinen, S.; Hankaniemi, M.M.; Huhtala, H.; Ruokoranta, T.; Lecouturier, V.; André, P.; Harju, R.; et al. Coxsackievirus B1 is associated with induction of $\beta$-cell autoimmunity that portends type 1 diabetes. Diabetes 2014, 63, 446-455. [CrossRef]

147. Stene, L.C.; Rewers, M. Immunology in the clinic review series; focus on type 1 diabetes and viruses: The enterovirus link to type 1 diabetes: Critical review of human studies. Clin. Exp. Immunol. 2012, 168, 12-23. [CrossRef]

148. Cacoub, P.; Terrier, B.; Saadoun, D. Hepatitis C virus-induced vasculitis: Therapeutic options. Ann. Rheum. Dis. 2014, 73, 24-30. [CrossRef]

(C) 2019 by the authors. Licensee MDPI, Basel, Switzerland. This article is an open access article distributed under the terms and conditions of the Creative Commons Attribution (CC BY) license (http://creativecommons.org/licenses/by/4.0/). 